\title{
The study of the black persimmon in China
}

\author{
Guoliang $\mathrm{Wu}^{1,2 *}$, Qunlong $\mathrm{LIU}^{3}$, Xiaohua Liu ${ }^{1,2}$, Aiqing $\mathrm{JI}^{4}$, Yanjun YANG ${ }^{1,2}$, Meiling KANG
}

${ }^{1}$ Coll. Hortic. Sci., Henan Agric. Univ., Zhengzhou, China, 450002, walnut-wu@126.com

2 Henan Key Lab. Fruit and Cucurbit Biol., Zhengzhou, China, 450002

${ }^{3}$ Coll. Hortic. Sci., Shanxi Agric. Univ., Taigu, China, 030801

${ }^{4}$ Dep. Biol. Sci. Technol., Jinzhong Coll., Jinzhong, China, 030600

${ }^{5}$ Dep. Biol. Sci. Technol., Zaozhuang Coll., Zaozhuang, China, 277160

${ }^{*}$ Correspondence and reprints

Received 13 February 2011 Accepted 5 January 2012

Fruits, 2012, vol. 67, p. 369-376 (C) 2012 Cirad/EDP Sciences All rights reserved DOI: 10.1051/fruits/2012031 Www.fruits-journal.org

RESUMEN ESPAÑOL, p. 376

\section{The study of the black persimmon in China.}

Abstract - Black persimmon in the literature. The persimmon (Diospyros kaki L.) is a deciduous fruit tree originating in China. One type consisting of a group of similar cultivars is the black persimmon, which is a precious germplasm resource of China. Black persimmon is mainly distributed in the south of the Taihang Mountains in northern China. Black persimmon is astringent, though this astringency can now be removed easily via normal maturity of the fruit. The skin of the fruit is black and the flesh has abundant nutritional value, with vitamin $\mathrm{C}$ and carotene. Information given by a black persimmon orchard. A trial on black persimmon was carried out from 2003 to 2009 in Zhengzhou, Henan province, China. Plant growth, yields and phenological characteristics were studied. The fruit has a thick skin which assists in storage and transportation; it has excellent flavor and quality, making the fruit highly valued by producers, marketers and consumers. Key cultivation techniques. Practices to achieve high quality are reviewed such as the proper plant environment, tree planting and pruning, the soil management, the wintering and protection of young trees, and pest control.

China / Diospyros kaki / land varieties / fruits / genetic resources / phenology / cultivation

\section{Étude sur le kaki noir en Chine.}

Résumé - Le kaki noir dans la littérature. Le kaki (Diospyros kaki L.) est un arbre fruitier à feuilles caduques originaire de Chine. Un type de D. kaki est constitué d'un groupe de cultivars semblables dont le fruit est noir ; c'est une ressource précieuse du matériel génétique de la Chine. Le kaki noir est principalement réparti dans le sud des monts Taihang dans le nord de la Chine. Le fruit du kaki noir est astringent mais cette astringence peut maintenant être facilement enlevée via la maturité normale du fruit. La peau du fruit est de couleur noire et la chair a une grande valeur nutritionnelle en vitamine $C$ et en carotène. Information donnée par un verger de kakis noirs. Une expérimentation sur le kaki noir a été réalisée de 2003 à 2009 à Zhengzhou, province du Henan, en Chine. La croissance, les caractéristiques phénologiques et les rendements des arbres ont été étudiés. Le fruit a une peau épaisse qui facilite le stockage et le transport ; sa qualité et son goût sont excellents, ce qui le rend très apprécié des producteurs, commerçants et consommateurs. Techniques culturales clés. Les pratiques permettant d'obtenir une production de grande qualité sont abordées comme le bon environnement végétal, la plantation des arbres et l'élagage, la gestion des sols, l'hivernage et la protection de jeunes arbres, et la lutte contre les ravageurs.

Chine / Diospyros kaki / variété indigène / fruits / ressource génétique / phénologie / pratique culturale 


\section{Black persimmon in the literature}

Recently, the popularity of black foods has increased, with more and more being marketed and achieving best-selling status in the market [1]. There are two reasons for this First, consumers consider these unusual foods to be fascinating and they want to taste them. Second, black foods possess abundant quantities of compounds with high nutritional value [1, 2]. Of these various black fruits, the black persimmon has a range of cultivars typically suited to and produced in Shanxi province in China [3]. Many years of observation have shown that the characteristics of persimmons are excellent and that they would seem to have considerable potential.

\subsection{Source of black persimmon cultivars}

The persimmon (Diospyros kaki L.) is a deciduous fruit tree originating in China. The black persimmon type group of cultivars is mainly distributed in the Zuoquan and Licheng counties of Shanxi province and the She county of Hebei province, which lie in the south of the Taihang Mountains in northern China. The black persimmon is of the astringent type, thus the astringency needs to be removed before fruit is suitable for consumption. This happens naturally upon ripening and cultivars of non-astringent (at maturity) black persimmon are kept in the National Persimmon Germplasm Nursery in Yangling, Shannxi province [4, 5].

\subsection{Black skin and abundant nutritional value of black persimmon}

The skin of the black persimmon has a glossy black pericarp when ripe. This is typical of black fruit. Just like black plum, black peach and black grape, it has higher levels of nutritional components and greater biocompatibility than normal fruit; moreover, it has many unique physiological and pharmacological functions (table I) [4, 6, 7]. Most persimmon cultivars are pistillate (female) and, while self-compatible, do not form seeds as they are planted without males to fertilize them. They can be sold as fresh or processed and products are well appreciated in the market $[1,8]$.

\subsection{Easy to remove astringency and good storage quality}

The fruit of black persimmon is of the astringent type, thus the astringency needs to be removed from fruit before eating. Compared with other persimmons, the astringency is removed naturally when it is ripened on the tree and the fruit is ready to eat when harvested, but the reason is unclear why this happens. When the ripe fruit is harvested it is not easy to store. If storage is required, the fruit should be harvested earlier when they are mature but still firm, with the skin color nearly fully developed into black. In cold places they can be stored for months; if they are kept in refrigerated conditions the fruit will keep longer. The skin is thicker so it endures transportation well [3, 9].

\subsection{Small tree allowing close spacing with high yields}

Tree height of black persimmon can reach about $4 \mathrm{~m}$ with a branch spread of about $4.5 \mathrm{~m}$. Fruit production was approximately $100 \mathrm{~kg}$ per tree with hundred-year-old trees.

\subsection{Survival on moderately fertile land and easy to manage}

Like any other kind of persimmon tree, black persimmon trees are not particular as to soil for growth, and they do well on any moderately fertile land. Few pests or diseases attack the fruits. Hence, black persimmon is very well suited for the development of new persimmon orchards.

\section{Information given by a black persimmon trial orchard}

To complement the information regarding characteristics of black persimmon already available, an orchard of about $6500 \mathrm{~m}^{2}$ was 
Table I.

Comparison of nutritional composition of black and other persimmons in China $[4,6,7]$.

\begin{tabular}{|c|c|c|c|c|c|c|c|c|}
\hline \multirow[t]{2}{*}{ Persimmon type } & Total sugar & Protein & Fat & Total tannin & Total carotene & Vitamin C & Total Ca & Total Fe \\
\hline & \multicolumn{4}{|c|}{ (\%) } & \multicolumn{2}{|c|}{$\left(\mathrm{mg} \cdot 100 \mathrm{~g}^{-1}\right)$} & \multicolumn{2}{|c|}{$\left(\mathrm{mg} \cdot \mathrm{kg}^{-1}\right)$} \\
\hline Persimmon & 13.8 & 0.4 & 0.4 & 0.01 & 1.9 & 30.0 & 120.5 & 22.0 \\
\hline Sweet Persimmon & 14.1 & 0.5 & 0.3 & 0.1 & 2.0 & 31.5 & 124.0 & 21.8 \\
\hline Black Persimmon & 14.3 & 0.7 & 0.4 & 0.1 & 2.1 & 39.2 & 138.1 & 23.5 \\
\hline
\end{tabular}

studied in Xingyang County, Henan province, from 2003 to 2009. The trial was located in the hilly land in the south of the Yellow River, where the climate is subtropical to mild-temperate. The zone has a cold winter and hot summer. In winter, the wind blows predominantly from the Northwest, while in summer, it blows from the Southeast. In the fall, the orchard has adequate sunshine. The average annual temperature is about $14.4^{\circ} \mathrm{C}$, while the highest temperature is $42.5^{\circ} \mathrm{C}$ and the lowest temperature is $-16.9^{\circ} \mathrm{C}$ [4]. The average annual rainfall is about $600 \mathrm{~mm}$; the average annual sunshine is about $2119 \mathrm{~h}$ and the continuous frost-free period 211 days [4, 8].

The experimental field had a sandy soil and the soil layer was deep. The young black persimmon plants came from Zuoquan County in Shanxi province (figure 1) and She County in Hebei province (figure 2). These black persimmon cultivars were compared with the local cultivar 'Xingyang Water Persimmon' (figure 3). Cultivars were planted at $3 \mathrm{~m} \times 2 \mathrm{~m}$, the $6-$ year-old trees reaching $8.7 \mathrm{~cm}$ in trunk diameter at ground level, with a tree height of about $3.9 \mathrm{~m}$, and a crown width of $2.22 \mathrm{~m} \times 2.19 \mathrm{~m}$. Generally, good local management techniques were used including irrigation and fertilizers with weeding and pest control as required. Fruit were all hand-harvested.

\subsection{The vegetative growth habit}

The tree crown of black persimmon is typically a cone in shape that is semi-open. The first year, branches looked grayish-green and reached up to about $16.9 \mathrm{~cm}$ long; the diameter of the stem base was $0.54 \mathrm{~cm}$.

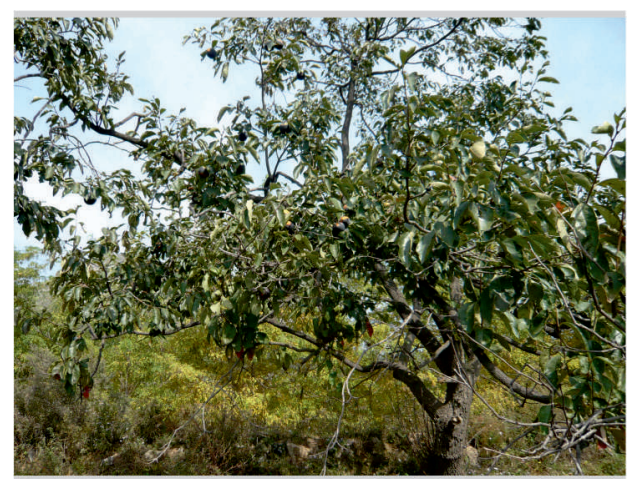

Figure 1.

A black persimmon tree from Zuoquan, Shanxi province, China, and the fruits.

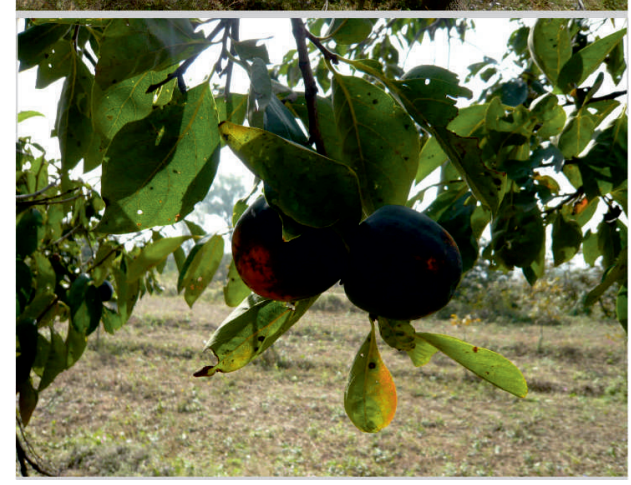

Generally, each bearing branch of the tree can accommodate 2-3 bearing shoots. Only female flowers are found on trees. The female flowers have a small semi-open corolla and the color of the petal is pale black. Every flower has four stigmas which unite in the lower parts. The ovary is in the middle with a green peak. The number of degenerated stamen was about six to eight and they were always scattered in order. There were nine leaves in every branchlet. The length of the leaf was about $20 \mathrm{~cm}$ and its transverse diameter was about $10.5 \mathrm{~cm}$. The leaf stalk was about $2 \mathrm{~cm}$ long with an internode space of $8 \sim 10 \mathrm{~cm}$. There was a strong parthenocarpic ability (table II) [2, 5]. 
Figure 2.

A black persimmon tree from She county, Hebei province, China, and the fruits.

Figure 3.

Young black persimmon trees from Xingyang, Henan province, China, and the fruits (6th year).

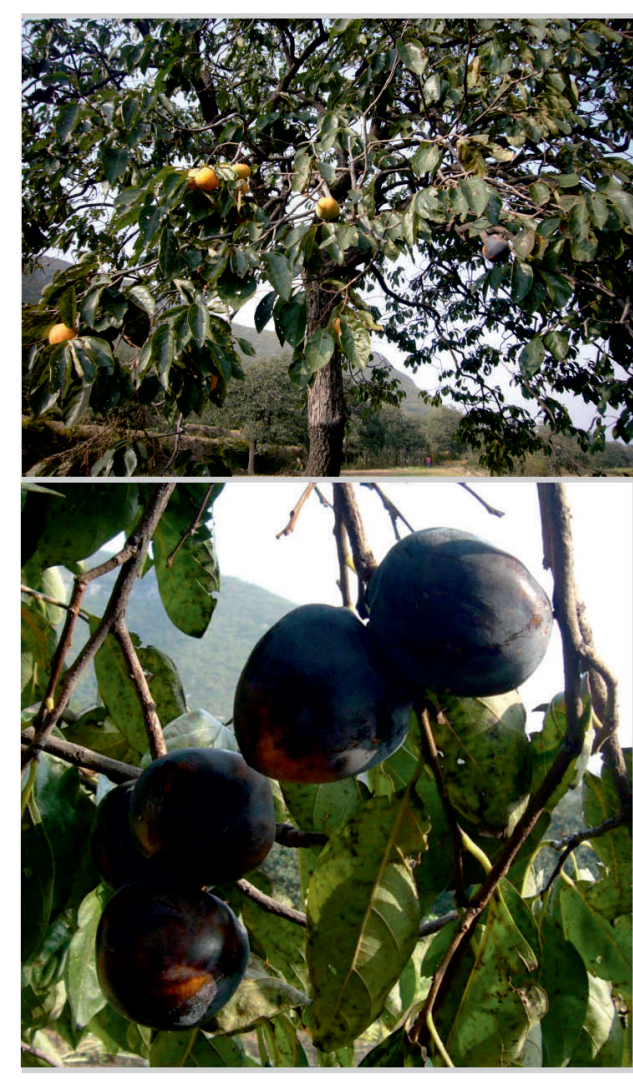

\subsection{Phenological period}

In the Zhengzhou area, black persimmon buds sprout in late March, with leafing out in mid-April and flowering in mid-May, with florescence lasting 3 7 days. Young fruits enter into their rapid fruit expansion stage in the first half of June. By the middle of September fruits begin taking on their yellow base color; black stripes then start to appear slowly and gradually expand, turning the total surface black when fruits ripen in midto late October. However, the fruit which lies in the internal regions of the crown or which is covered with leaves will still reveal a yellow background. Black persimmon fruit can be harvested and appear initially on the market when the fruit surface appears black in mid- to late October. Picking time can last until November. From the end of October to early November the leaves are falling and the tree goes into a dormant period. The fruit development period in our trial was 138-151 days, and vegetative growth was 231-225 days. A comparison with black persimmon of Shanxi Zuoquan, and introduced black persimmons from she County in Hebei showed that the development period of fruit was longer by 13 days for the She County persimmons, while the vegetative growth period was about 1 week shorter for the Shanxi black persimmon, with a later budding period and an earlier leaf fall period. When black persimmon was compared with the excellent native cultivar in Zhengzhou, 'Xingyang Shui Persimmon', there were no consistent differences in phenological phases (table II, unpublished data).

\subsection{Fruit characteristics}

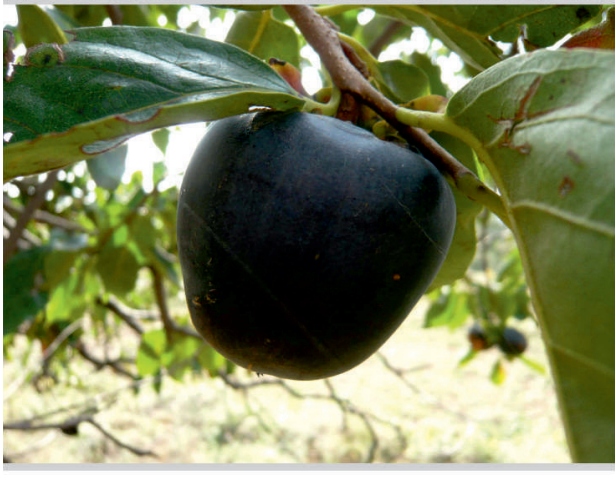

The black persimmon fruit size was median with an average fruit weight of $195.3 \mathrm{~g}$. The biggest fruit can amount to $270 \mathrm{~g}$, the average fruit length being $5.1 \mathrm{~cm}$ and breadth $4.8 \mathrm{~cm}$; the fruit shape index is 1.275 . The length of the largest fruit was $5.5 \mathrm{~cm}$, and the largest fruit breadth was $5.4 \mathrm{~cm}$. Fruit was heart-shaped with a jet black face, and much fruit powder which was also jet black. Wiping off the fruit powder resulted in exposing a jet black shiny skin. The peel 
Table II.

Phenophases of black persimmon and Xingyang-Shui persimmon grown in a Xingyang trial orchard from 2003 to 2009 (China).

\begin{tabular}{|c|c|c|c|c|c|c|c|}
\hline Persimmon cultivar & $\begin{array}{l}\text { Germination } \\
\text { stage }\end{array}$ & $\begin{array}{l}\text { Leaf- } \\
\text { expansion } \\
\text { stage }\end{array}$ & $\begin{array}{c}\text { Flowering } \\
\text { stage }\end{array}$ & $\begin{array}{l}\text { Mature } \\
\text { stage }\end{array}$ & $\begin{array}{l}\text { Abscission } \\
\text { stage }\end{array}$ & $\begin{array}{l}\text { Fruit } \\
\text { development } \\
\text { stage } \\
\text { (d) }\end{array}$ & $\begin{array}{l}\text { Vegetative } \\
\text { growth stage } \\
\text { (d) }\end{array}$ \\
\hline $\begin{array}{l}\text { Black persimmon } \\
\text { from Zuoquan } \\
\text { in Shanxi province }\end{array}$ & Late March & $\begin{array}{c}\text { Early and } \\
\text { middle April }\end{array}$ & $\begin{array}{l}\text { Middle } \\
\text { of May }\end{array}$ & $\begin{array}{c}\text { Middle and } \\
\text { late } \\
\text { October }\end{array}$ & $\begin{array}{l}\text { Late October } \\
\text { to early } \\
\text { November }\end{array}$ & 138 & 225 \\
\hline $\begin{array}{l}\text { Black persimmon } \\
\text { from She county } \\
\text { in Hebei province }\end{array}$ & $\begin{array}{l}\text { Middle } \\
\text { March }\end{array}$ & Late March & $\begin{array}{l}\text { Middle } \\
\text { of May }\end{array}$ & $\begin{array}{c}\text { Middle and } \\
\text { late } \\
\text { October }\end{array}$ & $\begin{array}{c}\text { Early } \\
\text { November }\end{array}$ & 151 & 231 \\
\hline $\begin{array}{l}\text { Xingyang-Shui } \\
\text { persimmon }\end{array}$ & Late March & $\begin{array}{c}\text { Early and } \\
\text { middle April }\end{array}$ & Late May & $\begin{array}{c}\text { Middle and } \\
\text { late } \\
\text { October }\end{array}$ & $\begin{array}{c}\text { Early } \\
\text { November }\end{array}$ & 153 & 216 \\
\hline
\end{tabular}

was rough, but with no mesh lines or cracks. The black persimmon fruit was without (or with extremely seldom) a shallow longitudinal groove [7, 9]. There was some constriction, which was in a cushion shape under the pedicel. The cross-section of the fruit was slightly squared-off round in shape with orange flesh. The flesh of hard persimmons is brittle and peel is difficult to remove when it turns soft. Soft persimmon pulp is sticky, has less juice and is very sweet in taste; soluble solids content could reach up to $22-26 \%$. Pith parts were small; the core was solid when ripping and there were eight ventricles with no seeds [9]. Fruit can be completely softened for consumption, but the softening process is slow. The thick skin is slightly wrinkled after softening, with the fruit having excellent storage and transportation qualities. The eating quality of black persimmon fruit was superior to that of normal persimmon. Upon ripening the black persimmon fruit lose their astringency naturally on the tree and the fruit are edible after picking. Fruit can be harvested from the time that the fruit surface is becoming black until it is turning soft [10].

The black persimmons grown in our trial were large (about $195.3 \mathrm{~g}$ per fruit depending on cultivar) [5, 6]. In hilly regions with suitable irrigation and good management, fruit size will be bigger. The fruit has distinct characteristics which make this variety unique: it has orange flesh, fine texture, more juice than other types and the fiber is thin and lower in quantity. The fruit has a fresh and strong flavor with a natural and agreeable mouth sense and can be sold fresh or processed. At present there is only a small production with superior characteristics so black persimmons have a high price at about 5 Yuan (RMB) $\mathrm{kg}^{-1}$ (US\$ 0.78) in the market. Generally, the annual value of production from well-managed 3- to 4-yearold trees can reach US\$ 11700 per ha and 5- to 7-year-old trees can range from US\$29250 to US\$ 38610 per ha. This is a greater return than that provided by other persimmon cultivars $[8,9]$.

\subsection{Bearing habit and production}

In the second year after replanting, twenty percent of grafted plants began fruiting, with a yield of about $500 \mathrm{~kg} \cdot \mathrm{ha}^{-1}$; the third year after planting all of the trees produced harvestable fruit. The average yield of black persimmon was $15,487 \mathrm{~kg} \cdot \mathrm{ha}^{-1}$. At 56 years after planting, the trees were in a high yield period with production of up to $(37,296$ to 54,612$) \mathrm{kg} \cdot \mathrm{ha}^{-1}$. At the prevailing market price for average quality fruit of 3 Yuan per $\mathrm{kg}$ (RMB), the output value will reach up to 7,500 10,922 Yuan ha $^{-1}$. Black persimmon was not only high yielding but smaller in tree height with numerous strong, 
Table III.

Growth and yield of black persimmon grown in a Xingyang trial orchard from 2003 to 2009 (China).

\begin{tabular}{lccccc} 
Investigation time & $\begin{array}{c}\text { Diameter at ground } \\
(\mathrm{cm})\end{array}$ & $\begin{array}{c}\text { Height } \\
(\mathrm{m})\end{array}$ & $\begin{array}{c}\text { Crown width } \\
(\mathrm{m} \times \mathrm{m})\end{array}$ & $\begin{array}{c}\text { Yield per tree } \\
(\mathrm{kg})\end{array}$ & $\begin{array}{c}\text { Yield } \\
\left(\mathrm{kg} \cdot \mathrm{hm}^{-2}\right)\end{array}$ \\
\hline Persimmon (2nd year) & 2.0 & 1.6 & $0.96 \times 0.85$ & $0.31 \mathrm{a}$ & 500 \\
Black Persimmon (2nd year) & 2.1 & 1.5 & $0.95 \times 0.81$ & $0.30 \mathrm{a}$ & 500 \\
Persimmon (4th year) & 4.8 & 3.3 & $1.90 \times 1.79$ & $10.3 \mathrm{~b}$ & 16650 \\
Black Persimmon (4th year) & 4.3 & 2.9 & $1.32 \times 1.29$ & $15.5 \mathrm{~b}$ & 17786 \\
Persimmon (6th year) & 8.9 & 4.2 & $2.53 \times 2.32$ & $22.4 \mathrm{c}$ & 37296 \\
Black Persimmon (6th year) & 8.7 & 3.9 & $2.22 \times 2.19$ & $32.8 \mathrm{~d}$ & 44612
\end{tabular}

Means within columns followed by different letters are significantly different by Duncan's multiple range test, $\alpha \leq 0.05$.

vigorous branches and thus well suited to high density planting (table III) [5, 7].

\section{The key cultivation techniques of black persimmon}

\subsection{The proper plant environment}

Our experience suggests that to successfully grow black persimmon the annual average temperature should be above $10^{\circ} \mathrm{C}$, the minimum temperature no lower than $25^{\circ} \mathrm{C}$, and the frost-free period must be more than 170 days; in districts without irrigation conditions, annual precipitation needs to be above $400 \mathrm{~mm}$ [3]. The soil should be neutral, slightly alkaline or mildly acid, with salinity below $0.3 \%$; it should be deep and rich, with better than average water-holding capacity. Consequently, most of north China and some of the northwest regions of China would seem suitable for planting black persimmon [4].

\subsection{Planting and pruning}

The black persimmon cultivar used in our trial has the ability to produce parthenocarpy [11]. There was thus no need to include pollination cultivars in the planting. Planting density depends on the soil conditions, moisture availability and management techniques. Regions should adopt a lower planting density where the available management technology is lowest; except in rich soil and high precipitation, the advisable planting distances under these conditions would be $4 \mathrm{~m} \times 5-6 \mathrm{~m}$.

Generally, the trees' natural shape was an open-center shape or a layered shape after stem thinning at a stem height of $0.8 \mathrm{~m}$. Summer pruning was the principal thinning in tree training, and then winter pruning was a supplementary process. As many branches as possible should be left during the thinning, using relaxed pruning on the condition that the tree is not disorderly. In the full bearing period and later, it is most important to adjust the relationship between fruit-set and growth by appropriate thinning [11, 12].

\subsection{Soil management}

As it was believed that the deep soil could provide adequate response to improved fertility a base fertilizer was applied in our trial. This fertilizer was mainly organic fertilizer (5 kg per tree) [9]. Application was a small amount applied many times. Inorganic potash fertilizer was also applied $(0.1 \mathrm{~kg}$ per tree) [9]. Persimmon trees have a deep root system and, as a result, can withstand drought to a certain extent. However, the trees are not physiologically drought-resistant. They are very sensitive to water shortage, so the areas without ability to apply supplementary water should adopt water conservation measures [13]. 


\subsection{Overwintering and protection of young trees}

In the northern region, owing to high winds and low temperatures in spring, persimmon saplings often sprout too soon, resulting in dead trees or broken branches. To prevent this happening, the young trees should not have nitrogen fertilizer applied and irrigation should be controlled after the middle of August. A leaf surface spray of $0.3 \%$ potassium phosphate enhances branch maturity $[7,9,10]$.

\subsection{Pest control}

Black persimmon is subject to damage by the pest Phenacoccus pergandei Cockrell, which is an important reason for late fruit drop. Therefore, farmers should focus on the prevention and control of that pest. In addition, they should also apply timely control for leaf spot of persimmon (Kakivoria flavofasciata Nagano) and Hypocala subsatura Guenee, etc. The fungicide Bordeaux mixture (1:2-3:500) or a solution of thiophanate-methyl at 1:800 dilution should be sprayed once in June. During the risk period of Kakivoria flavofasciata Nagano, a 1000 -times diluted application of $50 \%$ original strength of O,O-dimethyl-O-2,2-dichlorovinyl phosphate (DDVP) can be sprayed. DDVP or methamidophos (1:2000 dilution) can be applied to prevent Phenacoccus pergandei Cockrell. and Hypocala subsatura Guenee [9, 10, 13].

\section{Acknowledgements}

We thank the National Persimmon Germplasm Nursery in Yangling, Shanxi province, China, for providing support for this research. Dr. Zhengrong Luo and Dr. Qinglin Zhang (Agric. Univ. Huangzhong) are also acknowledged for the extensive help they provided. We thank Prof. David L McNeil (Univ. Tasmania, Australia) for his kind guidance for this paper. This work was supported by the Key Project of Science and Technology of Henan, China (No. 092101110600).

\section{References}

[1] Wang Peng, Han Wei, Wang Wen-Liang, The nutrition and health function and developing prospects of black food in China, Mod. Agric. Sci. Technol. 17 (2010) 359-362.

[2] Ding Xiangyang, The study of black persimmon introduction and its cultural techniques, H. Henan For. Sci. Technol. 25 (4) (2005) 6-7 (in Chinese).

[3] Fu Gengfu, Fruit germplasm resources and regionalization in Shanxi province, For. Press, Beijing, China, 1995 (in Chinese).

[4] Wang Zhongying, The records of Shanxi fruits, Econ. Press, Beijing, China, 1995 (in Chinese).

[5] Yang Yong, Li Gaochao, Wang Renzi, Black persimmon, Northwest Hortic. 1 (1999) 34 (in Chinese).

[6] Su Caihong, Guo Chuangye, The study of the fruit characters and the analyses of the nutritional components related to quality of nonastringent persimmons, Spec. Wild Econ. Anim. Plant Res. 3 (2001) 35-38 (in Chinese).

[7] Zhang Yaozhan, Chu Aixiang, Chen Xiangyang, Li Yanmei, Ji Yanwei, Rare and precious fruit - black persimmon introduction and cultural techniques, Fruit Grow. Friendsh. 4 (2005) 19 (in Chinese).

[8] Wang Xiaochun, Black persimmon introduced in Tianshui of Gansu province, NonWood For. Res. 26 (1) (2008) 74-77 (in Chinese).

[9] Zhu Yuanqing, Black persimmon introduction and cultural technique, Shandong For. Sci. Technol. 4 (2006) 69-70 (in Chinese).

[10] Dai Guilin, Song Xiaodong, Nie Guowei, Yang Xiaohua, Seedless black persimmon characteristics and cultural techniques, Shanxi Fruits 1 (2005) 40-41 (in Chinese).

[11] Sugiyama N., Yamaki Y.T., Effects of CPPU on fruit set and fruit growth in Japanese persimmon, Scientia Hortic. 60 (3) (1995) 337343.

[12] George A.P., Collins R.J., Nissen R.J., Growth, yield, and fuit quality of two nonastringent persimmon (Diospyros kaki) cultivars, Izu and Fuyu, in subtropical Australia, Aust. J. Exp. Agric. 34 (2) (1994) 267-275.

[13] Li Xiaomeng, Ding Xiangyang, Effects of PP333 on black persimmon growth, For. Sci. Technol. Dev. 22 (5) (2008) 101-102 (in Chinese). 


\section{El kaki negro en China.}

Resumen - El kaki negro en la literatura. El kaki (Diospyros kaki L.) es un frutal de especie caducifolia originario de China. Un tipo de D. kaki está constituido por un grupo de cultivares semejantes, cuyo fruto es negro; se trata de un recurso preciado del material genético de China. El kaki negro está repartido principalmente al sur de los montes Taihang, al norte de China. El fruto del kaki negro es astringente, pero esta astringencia puede eliminarse fácilmente a través de la madurez normal del fruto. La piel del fruto es de color negro y la pulpa posee un gran valor nutricional en vitamina $\mathrm{C}$ y en caroteno. Información proporcionada por un vergel de kakis negros. Se llevó a cabo un experimento en el kaki negro de 2003 a 2009 en Zhengzhou, provincia del Henan, en China. Se estudiaron el crecimiento, las características fenológicas y los rendimientos de los ábroles. El fruto tiene una piel espesa que facilita el almacenamiento y el transporte; su calidad y su sabor son excelentes, lo que lo hace ser muy apreciado por los productores, comerciantes y consumidores. Técnicas de cultivo claves. Atañen las prácticas que permiten obtener una producción de gran calidad, como el buen entorno vegetal, la plantación de los árboles y la poda, la gestión de los suelos, el invernadero y la protección de los árboles jóvenes, y la lucha contra las plagas.

China / Diospyros kaki / variedades indígenas / frutas / recursos genéticos / fenología / cultivo 